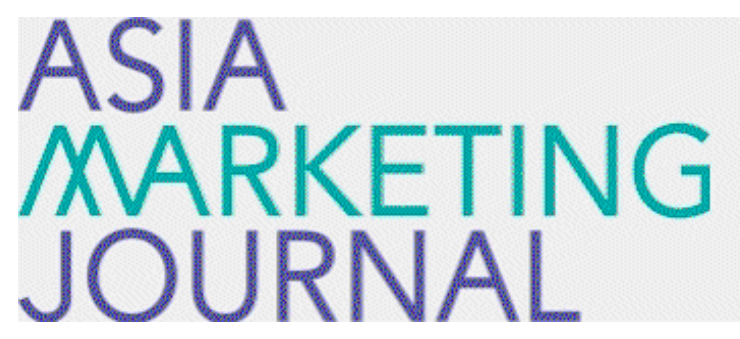

ASIA MARKETING JOURNAL

Volume 5 | Issue 4

Article 5

$12-25-2003$

\title{
신화를 창출한 애니콜의 브랜드 전략
}

소은 현

민희 한

종석 예

Follow this and additional works at: https://amj.kma.re.kr/journal

Part of the Marketing Commons

\section{Recommended Citation}

현, 소은; 한, 민희; and 예, 종석 (2003) "신화를 창출한 애니 콜의 브랜드 전략," Asia Marketing Journal: Vol. 5 : Iss. 4 , Article 5.

Available at: https://doi.org/10.53728/2765-6500.1116

This Article is brought to you for free and open access by Asia Marketing Journal. It has been accepted for inclusion in Asia Marketing Journal by an authorized editor of Asia Marketing Journal. 


\title{
신화를 창출한 애니콜의 브랜드 전략*
}

\section{Anycall: Building a Powerful Brand}

\author{
현소은 (동덕여대 경영경제학부 조교수) \\ soeun1edongduk.ac. kr \\ 한민희 (Kaist 테크노경영대학원 교수) \\ mhhahnêkgsm.kaist .ac.kr \\ 예종석 (한양대학교 경영학부 교수) \\ yejs(cemail hanyang.ac. $\mathrm{kr}$
}

본 사례는 한국인의 자존심을 상징한다고까지 극찬하는 애니콜 브랜드의 성공신화가 어떻게 창출되었는지 밑바탕이 된 마케팅 전략을 분석한다. 21 세기의 디지털 세상에서 살아가는 소비 자들에게 가장 가까운 친구로 등장한 휴대폰, 그 휴대폰 시장에서 해외 유명브ㄹㅐㅐ드를 제치고 국내시장을 석권했을 뿐 아니라 세계의 소비자로부터 최고 제품으로 인정 받게 된 이면에는 치밀한 브랜드전략이 있었다. 애니콜이라는 브랬드를 소비자의 마음속에 뚜렷하게 각인시키는 데 기여했던 노력들을 더듬어 보고, 그 주효했던 전략들을 검토해 본다. 마지막으로 애니콜 의 새로운 도약을 기대하며 향후의 마케팅전략방향을 제시하였다.

* 사례접수 : 03.11 게재확정 : 03. 12 


\section{1. 서론}

세계 최고의 경쟁력을 향해 질주하고 있는 애니콜은 우리 국민들의 자부심이자 가장 주목 받는 독보적 브랜드이다. 2조 380억원 (브랜드 에쿼티 모델 2002.7)의 브랜드 자산가치를 자랑하며, 국내시장에서는 시장점유율 $58 \%$ 의 독보적 리더로서 2 위인 $\mathrm{L}$ 사의 시장점유율 $25 \%$ 를 배이상으로 따돌리고 있다. 또한 애니콜 신화는 모토롤라나 노키아등 세계적 유명브랜드 의 국내시장 잠식 완전 저지에 성공한 특별한 사례이다. 세계시장에서도 애니콜은 한국 및 중국에서는 애니콜 브랜드로, 기타지역에서는 삼성브랜드로 팔리며, 노키아(33.4\%), 모토로 라(15.7\%)에 이어 세계시장 3 위를 달리고 있다.

이러한 애니콜 브랜드의 성공전략은 신화라고 불리기에 손색이 없다. 특히 휴대폰이 우리 나라에 처음 상륙한 84 년부터 10년이상 국내시장에서 아성을 구축했던 세계적 기업 모토로 라를 제치고 95년부터는 마켓 리더로서의 독주를 계속하고 있다. 애니콜은 판매율뿐만 아니 라 확고한 인지도를 달성하고 있다. 애니콜은 최초 상기율 $97.3 \%$ 를 보이고 있으며 (국내 L 사: $78.3 \%$, 해외 M사: $75.7 \%$ ), 비보조 상기율에서는 $60 \%$ 를 나타내고 있다(국내 L사: $15.3 \%$, 해외 M사: 8.3\%) (제일기획 2001. 7 조사)(표 1). 브랜드 호감도에 있어서도 애니콜 브랜드 는 $87.6 \%$ 로 국내 L사의 $50.5 \%$, 국내 S사의 $64.1 \%$ 에 비해 압도적 지지를 받고 있는 것으로 나타났다 (중앙 리서치 조사 2001. 6) (표2), 이러한 지수를 보더라도 애니콜은 우리국민들 로부터 가장 사랑받는 브랜드임에 틀림없다.

이 사례는 애니콜의 브랜드 전략이 함축한 중요한 전략적 시사점을 찾아보고자 한다. 애니 콜 팀이 기획하고 실천한 마케팅 전략을 되짚어 보며 애니콜의 성공요인을 분석해 보는 것 은 마케팅을 공부하는 많은 경영학도와 마케팅 담당자에게 좋은 학습 기회를 제공하리라 기 대한다. 또한 이 사례를 통해서 앞으로 애니콜 브랜드전략이 어떻게 기획되어야 할 것인지 를 생각하게 하는 좋은 자료가 될 것으로 생각된다. 
(표1) $\mathrm{Br}$ and Power Index

애니콜은 확고한 인지도 파워 달성

특히, 2 위 $L$ 사 대비 대표성 지수에서 큰 격차를 보임

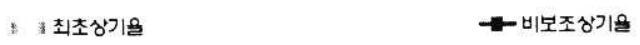

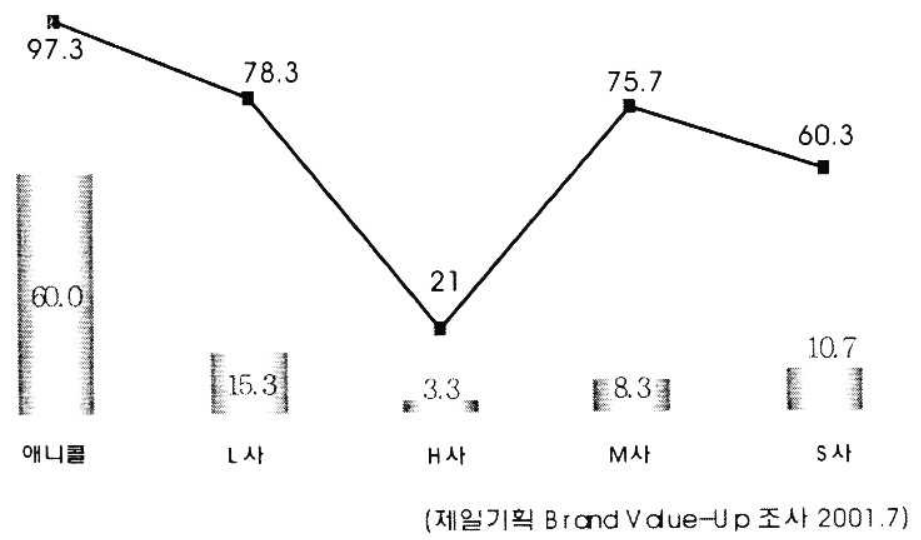

(표2) $\mathrm{Br}$ and Performance Index

\section{압도적 브랜드 호감도 확보}

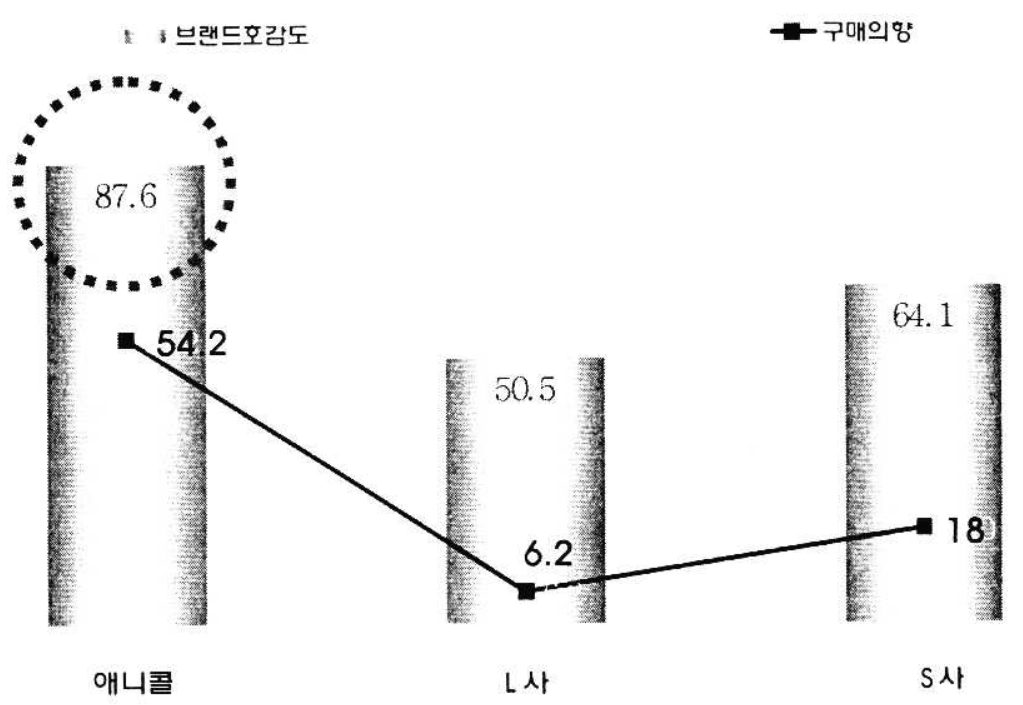

(중앙리서치 조사 2001.6) 


\section{2. 애니콜 브랜드의 출범}

애니콜 브랜드의 역사는 93년 11월에 출시된 SH-700의 탄생부터 시작한다. 당시 국내 휴 대폰 시장은 우리나라에 제품이 소개된 84 년 이후 매년 $100 \%$ 이상의 급신장을 계속해왔지만, 국내 업체들은 기술력에서 뒤쳐져있었고, 글로벌 브랜드인 미국의 모토로라가 시장 성장의 최대 수혜자로서 독주를 하는 상황이었다. 그러나 이동통신사업이 21 세기 핵심사업이 될 것 임을 예감한 삼성전자는 SH-700이라는 $100 \mathrm{~g}$ 대의 당시로서는 획기적인 휴대폰을 개발함으로 써 애니콜 브랜드 신화를 창출하는 계기를 마련하였다.

이 제품은 휴대폰 개발진들이 전국을 돌며 통화상태를 점검하여 산악지형이 많은 한국 지 형에 적합하도록 최적의 통화 성공율을 구현할 수 있도록 회로를 설계하였다. 또 가지고 다 니기 편리한 휴대폰을 만들기 위해 기존의 모든 부품을 소형화하여 휴대폰의 무게와 부피를 줄였고, $870 \mathrm{~kg}$ 의 하중을 견딜 수 있도록 개발되었다. 이 제품은 93 년 10 월에 출시되었으나 완벽한 품질을 위한 전수검사등으로 생산량이 매우 적어 93년 휴대폰 시장에서는 커다란 변 화를 일으키지는 못하였다. 다만 시장진입이라는 1 차 목표를 무난히 달성하는데 만족한 정 도였다. 94 년도에도 이 제품 품질력이 확실하게 안정되었으며, 판매촉진 활동을 적극적으로 하여 경이적인 판매신장을 실현하였다. 가격이 높아 판매가 크게 확대되지 못하던 국내 휴 대폰 시장에서 삼성전자는 휴대폰 보급화를 위해 $20 \%$ 이상 가격을 인하하고, 업계최초로 구 형 휴대폰의 교체흡수를 위한 교환 판매를 시행하였으며, 청약금 포함 할부 판매제를 도입 하여 소비자의 부담을 줄여나갔다. 그리고, 전국 주요 명산에서 무료통화 이벤트를 시행하 는 등 업계 최초의 새로운 판촉활동으로 큰 효과를 거두어 내었다.

이 무렵 삼성전자는 홋날 신화를 창조하게 될 애니콜 브랜드를 출범시킨다. 94년도의 경 이적 신장이 있었지만 모토롤라의 브랜드 파워를 누르기에는 역부족이라는 것을 간파한 삼 성전자는 장기적으로 자체 브랜드가 필요하다는 판단아래 수백개의 브랜드 후보안을 놓고 심사숙고하여 '애니콜' 브랜드를 탄생시킨다. 새로운 브랜드의 탄생을 위해 공모를 하였고 5 천여통의 제안이 들어오기도 했지만 정작 사업팀의 마음을 사로잡은 것은 당시 사업부장이 던 오 정환 전무가 제안한 '애니텔' 이란 이름이었다고 한다. 그러나 상표권 조사에서 독 점적 사용이 곤란하다는 분석이 나와 회의를 거듭한 끝에 오전무가 다시 제안한 '애니콜' 로 결정이 되었다. 그러나 이 이름이 불과 몇년 후에 몇 조의 브랬드 자산으로 평가받는 기 적을 이루리라고는 아무도 생각지 못했다. 오히려 애니콜로 결정해 놓고도 '애니(Any)' 가 갖는 부정적 의미와, 콜걸 등에서와 같이 '콜(Call)' 이 갖는 저속한 이미지로 인해 부정 적인 효과가 나타나지 않을까 하고 불안하게 생각한 사람도 있었다고 한다. 하지만 '우리 가 키워가자' 란 사업팀의 신념은 결과적으로 10 억불 이상의 가치로 평가되는 대한민국 글 로벌 브랜드를 만들어 내고야 만 것이다.

1994년 10월 애니콜이라는 이름으로 출시된 SH-770은 SH-700의 기능을 보완하고 국내 최 초로 수소 배터리를 채용하여 배터리 사용기간을 개선한 제품이었다. 휴대폰 업계 최초로 전국을 돌며 3,000 여개의 대리점을 대상으로 초청 신제품 발표회를 가지는 등 적극적 인 마 케팅 활동에 힘입어 94 년에는 $26 \%$ 대의 시장 점유율로 전년대비 $10 \%$ 이상의 획기적인 신장을 하였다. 이때부터 삼성전자는 모토로라의 독주에 제동을 걸기 시작한다. 1994년 휴대폰 시 장의 폭발적 증가는 1995년으로 이어졌고 이 절호의 기회를 내것으로 하기위해 애니콜 은 “한국지형에 강하다" 라는 슬로건을 만들어내게 된다. 이는 삼성 휴대폰의 개발 컨셉 
트로서 산악지대가 많아 전파가 약한 한국지형에 적합하게 설계된 독자기술의 산물이었다. 제품 출시 후 이 제품의 높은 통화 성공률이라는 경쟁우위 포인트를 광고, 프로모션 등을 통해 전방위로 커뮤니케이션 하였다. 판매촉진 수단으로 '천왕봉 프로젝트' 도 시행되었는 데, 주말이면 모든 임직원이 팀을 짜 북한산, 관악산 등 전국의 명산에 올라 무료통화 시연 회를 여는 프로그램이었다. 2 차 캠페인을 통해서는 15 곳의 명산, 4 곳의 섬, 4 곳의 바닷가, 그리고 역사의 고도 경주가 시연장소로 선정돼 무료통화시연이 진행되었다. 성능검증을 위 해 삼성전자의 임직원들이 강원도 산골까지 수십 $\mathrm{kg}$ 짜리 장비를 짊어지고 들어가 테스트하 다 간첩으로 몰린 에피소드도 있다. 이외에도 소비자들의 제품력에 대한 감동의 제보도 크 게 한 몫을 했다. 하루는 소비자로부터 소나타에 애니콜이 깔렸는데도 망가지지 않았다는 제보가 있었는데, 이후 이 사례는 광고에서 성우 배한성이 애니콜을 떨어뜨리고 다시 주워 서 통화를 하는 씬의 소재로 활용되어 견고감을 자연스럽게 강조하는데 일조하였다. 불에 탔는데 애니콜이 작동되더라는 소비자의 제보는 "애니콜의 성능은 불타지 않았습니다" 라 는 광고카피와 함께 불난 집에서 뛰쳐나오는 안성기가 애니콜로 전화를 거는 광고로 만들어 지기도 했다. 그 밖에 바다에서 낚시를 갔던 사람이 물에 빠졌는데 갖고 있던 애니콜로 구 조요청을 하여 목숨을 건진 사례, 성수대교 붕괴시 사건을 맨 먼저 알렸던 애니콜, 차와 함 께 떨어졌으나 애니콜로 연락하여 긴급구조를 요청했던 사건 등을 마케팅에 적극 활용하여 구전 마케팅의 효과를 극대화하였다. 이러한 커뮤니케이션전략은 드디어 시장을 움직이기 시작했고 1995년 7월 결국 애니콜은 시장점유율 $52 \%$ 로 모토롤라의 $42 \%$ 를 누르고 선두주자로 나서게 된다. 모토로라의 아성이 무너지고 애니콜신화가 태동하는 순간이었다. 그 후 연이 어 나온 SH-800 시리즈는 최고급 모델이 외국산 제품이 아니라 국산제품인 삼성의 애니콜이 라는 인식을 소비자에게 심어주었고, 이 때부터 애니콜은 대한민국 국민에게 사랑받는 국민 브랜드로, 더 나아가 글로벌 브랜드로 부상하게 된다.

(표3) '93-' 95. 2/4분기 HHP $\mathrm{M} / \mathrm{S}$ 현황 (삼성 vs 모토로라)

\begin{tabular}{|c|c|c|c|c|}
\hline 구분 & '93년 & '94년 & '95년 & '96년 \\
\hline 삼성전자 & $15 \%$ & $26 \%$ & $52 \%$ & $51 \%$ \\
\hline 모토로라 & $56 \%$ & $53 \%$ & $46 \%$ & $10 \%$ \\
\hline 기타 & $29 \%$ & $21 \%$ & $9 \%$ & $39 \%$ \\
\hline
\end{tabular}

(표4) 삼성 vs 모토로라의 전체적 소비자 만족도 변화

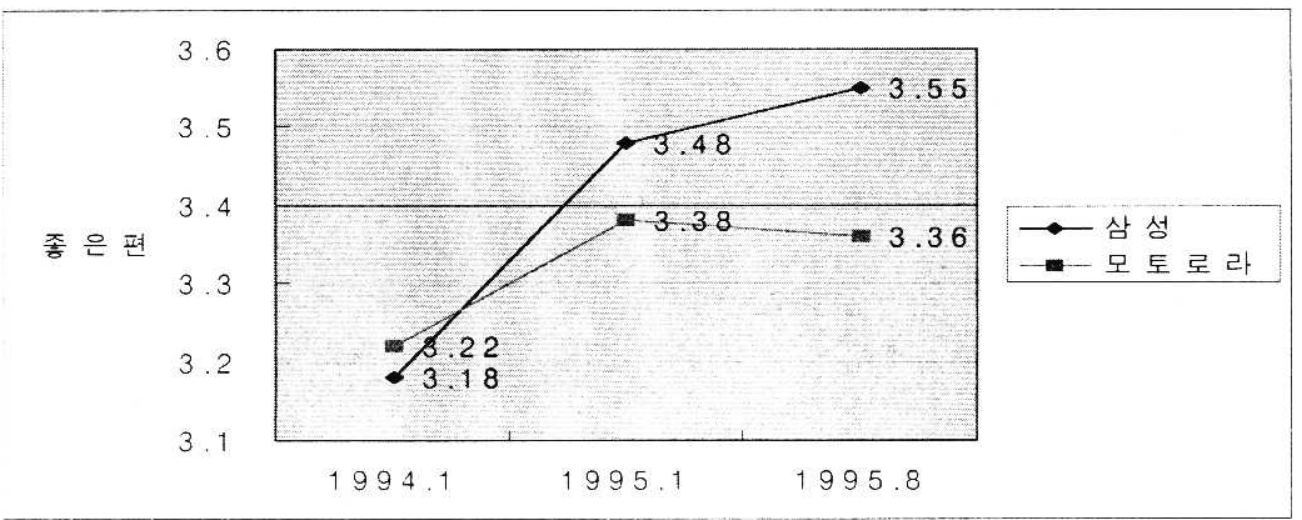




\section{3. 시장환경변화에 따른 브랜드 구축전략}

\section{1 제 1 기 차별화기 $\left(94.8^{-98.6)}\right.$}

93년 삼성 브랜드로 휴대폰 사업을 시작한 뒤 이어서 애니콜 브랜드를 출범시켜 시장의 주도권을 잡아나가는 시기이다. 시장진입 초기에는 모토로라의 독주 (M/S 70\%이상)가 10년 이상 지속되는 시점이었고, 비즈니스 사업자 중심으로 휴대폰 수요가 늘어나고 있었으며, 삼성은 93 년도에 겨우 $15 \%$ 대의 $\mathrm{M} / \mathrm{S}$ 를 확보했을 뿐이었다. 그러나 한국지형에 적합하도록 개 발된 삼성의 휴대폰에 자부심을 갖고, 94 년 8월에 애니콜 브랜드를 출범시킨다. 다윗과 골 리앗의 싸움이라고 할 수 있는 싸움에서 애니콜은 모토로라란 거대한 공룡을 95년부터 제압 하기 시작한다. 이러한 애니콜의 도약은 휴대폰의 중심가치가 통화성공률이라는 최고의 마 케팅 포인트를 찾아낸 데 기인한다고 해도 좋을 것이다. 모토로라 제품은 미국의 평야 지대 에 맞게 설계되어 통화성공률이 낮은 반면, 산악지형이 $70 \%$ 이상인 한국에서는 우리지형에 맞게 설계된 애니콜이 적격이라는 자부심이 빚어낸 승리였다. 이러한 마케팅 포인트를 구체 화시키기 위해 95 년 1 월부터 '한국지형에 강하다' 캠페인을 전개하여 전국 주요명산 무료 통화 시연회, 추석 귀향길 무료통화 시연회 등을 가졌고, 100 만 명이 참여하는 구전 마케팅 을 벌였다. 이 캠페인을 위해 삼성전자의 임직원과 전국의 영업사원들은 혼연일체가 되어 휴일을 반납하기까지 했다고 한다. 그 결과 애니콜은 95 년 $52 \%$ 의 시장 점유율로 모토로라를 제치고 시장 선두에 나서게 된다. 이어서 애니콜은 우리나라에서 최초로 CDMA기술을 상용화 했고 또한 최경량 $(170 \mathrm{~g}$ 대), 진동기능 및 장기사용을 위한 리튭 배터리 기능을 내장한 제품 을 개발한다. 이러한 우수제품의 출시로 세계 최고급 모델이 외국산 제품이 아니라 국산 제 품인 삼성 애니콜임을 소비자에게 심어주었고, 이에 힘입은 판매성장으로 외화 유출을 막을 수 있었다. 반면 모토로라는 96년 '디지털 휴대폰 시기' 가 도래함을 방관하여 적기 대응 에 실패했고, 시장점유율은 $10 \%$ 까지 추락하는 수난을 격게 된다. 이 시기의 애니콜 성공의 주요인을 분석해 보면 삼성의 기술력이 우수한 제품을 개발했고 제품의 우수성을 효율적으 로 전달한 통합 커뮤니케이션에 힘입어 최고급 브랜드 이미지 구축에 성공한 것이라고 볼 수 있다.

\section{2 제 2 기 확장기 $(97.10-98.6)$}

97년 10월 1 일 한국통신프리텔, 한솔 PCS, LG텔레콤 등 3 사에 의해서 PCS서비스가 시작 되면서 휴대폰 시장은 새로운 전기를 맞게 된다. 사업자들의 공격적인 마케팅에 힘입어 시 장이 급속도로 확장되어가는 호기를 맞은 것이다. PCS라는 새로운 서비스에 대응하기 위해 서 애니콜은 새로운 소구점을 찾아내는데, 그동안의 성공에서 입증된 기술력이 애니콜 PCS 의 통화 음질에도 이어진다는 점이었다. 이러한 소구점을 소비자에게 효과적으로 알리기 위 해 '작은 소리에 강하다' 라는 슬로건이 등장하였는데, 미세한 소리까지 놓치지 않고 잡아 내는 우수한 통화음질을 주장하는 것이었다. 이 슬로건은 신세대에게 최고의 인기를 누리고 있던 김희선, 장동건을 광고에 등장시켜 효과적으로 파급되었고, 또한 ARS을 활용한 '목소 리 편지' 등 다양한 IMC(Integrated Marketing Communication) 전략도 구사되었다. PCS의 
주요타겟인 젊은 층에게 상당한 호응을 받음으로써 단기간 내에 시장에 진입하는데 결정적 인 역할을 해내었다.

이러한 PCS시장진출과 함께 CDMA 기본수요도 계속 확대해 나아갔다. 이 시기에 애니콜의 주요타겟층이 비즈니스층에서 일반 사용자층으로 시장확대가 이루어졌다. 특히 삼성전자는 홍콩에 이어 세계에서 두 번째로 CDMA방식 디지털 이동전화서비스를 우리나라에서 상용화했 다. $\mathrm{CDMA}$ 종주국인 미국조차 상용화를 시도하지 못한 상황에서 우리나라의 성공은 외국 경쟁 기업들을 놀라게 하였다. 따라서 97 년 이후 CDMA $57 \%$, PCS $58 \%$ 의 M/S를 달성, 부동의 대표 브랜드로 자리잡아가는 시기라고 할 수 있다.

또한 이시기에 올림픽 공식 스폰서 자격을 획득하여 강력한 프로모션 활동을 전개하기에 이르렀다. 2000 년 밀레니엄 시대를 여는 시드니 올림픽에서 전세계를 대상으로 마케팅을 할 수 있는 기회를 얻어낸 것이다. 올림픽 공식 스폰서로서의 마케팅은 국내뿐 만이 아니라 세 계를 대상으로 진행되었는데, 애니콜은 이러한 올림픽 스폰서 쉽을 활용하여 다양한 올림픽 마케팅을 시행하게 된다. 첫 번째로 올림픽 전용모델을 개발하였다. 휴대폰의 패키지를 올 림퍽컨셉으로 디자인하고 제품에는 올림픽 로고를 $21 \mathrm{~K}$ 로 도금한 배지를 부착한 애니콜 올림 픽폰을 출시하여 그해 하반기 주력모델로 부상시켰다. 그리고 고객참여와 주요거래선에 대 한 호스피텔리티 프로그램도 성황리에 진행시켰다.

이 시기의 주요 성공 포인트는 애니콜의 제품력을 바탕으로 한 최고급 품질이미지가 '통 화음질' 이라는 새로운 속성을 통해 추가적으로 부각되었다는 점을 들 수 있다. 소비자 조 사 결과에서도 애니콜이 '통화성공율' 과 '통화음질' 이라는 통화품질의 두 요소에서 모 두 경쟁사 대비 절대적인 우위를 점하는 것으로 나타났다. 결과적으로 CDMA기본 수요를 확 대시켜나갔을 뿐만 아니라 PCS를 통한 시장확대도 가속화되었다. PCS로 브랜드 확장이 성공 한 것이다. 다만 CDMA와 PCS의 이원화로 마케팅 효율성이 저하될 수도 있다는 우려를 낳게 된다.

\section{3 제 3 기 대표성 획득기 $(98.7$ - 99.8)}

이 시기는 명실공히 N0.1 브랜드로서 수요의 대중화를 일으킨 기간이었다.

시장 상황은 모토로라가 재등장하기 시작했고, SKY등 사업자 모델이 가세하여 경쟁이 가속 화되는 시점이었다. 제품도 플립형, 슬림형 등 카테고리가 다양해짐에 따라 단순 통화품질 에서 부가기능으로 소비자의 욕구가 세분화되어가고 있었다. 하지만 이러한 경쟁상황을 돌 파하기 위해 '한국의 자존심을 지킨다' , '언제 어디서나 한국인은 애니콜' 이라는 슬로 건으로 소비자들의 애국심에 호소하는 마케팅 전략을 구사한다. 이 슬로건을 효과적으로 커 뮤니케이션하기 위해 세계의 골프 애호가들에게 찬사를 받는 박세리를 광고에 등장시켜 한 국 대표브랜드라는 이미지를 강력히 심어주었다. 이러한 노력을 뒷받침하기 위해 인구밀집 지역을 찾아가는 서비스와 같은 고객 로열티 제고 프로그램을 운영했고, 애니콜 송을 만들 어 전파하고 캐릭터를 공모하는 등 고객 참여형 이벤트를 활성화하였다. 또한 대표 브랜드 로서의 문화선도 캠페인으로 대학교나 지하철 등 공공 장소에서 휴대폰 에티켓 캠페인을 행 사하였다.

그 결과 애니콜 판매량은 폭발적 성장을 이루어 97 년 2,898 천대에서 98 년 5,069 천대, 99 년 7,143천대를 달성하였다. 하지만 치열한 경쟁으로 인해 시장점유율은 $50 \%$ 이하로 저하되 는 상황도 맞이하게 된다. 브랜드 이미지 중심광고로 차별적 우위요소의 강조가 약화된 점 
이 그 이유로 분석된다.

\section{4 제 4 기 세분화기 $(99.9-01.2)$}

이 시기의 시장 환경은 교체수요가 확대되고, TTL, n016등 20대 영타겟이 신규 주력시장 으로 부각되는 시점이었다. 따라서 젊은 세대를 타겟으로 하는 경쟁 브랜드의 도전(L사의 대화면 $\mathrm{LCD}, \mathrm{M}$ 사, $\mathrm{S}$ 사등의 디자인 소구등)이 심화되었다. 이러한 난관을 타개하고자 삼성전 자는 '내 손안의 디지털 세상' 이라는 슬로건아래 연속적으로 폴더형 힛트 제품을 내 놓 으면서 브랜드 리더쉅을 강화해 나갔다.

$\mathrm{CDMA}$ 시장에서 주도권을 획득한 삼성은 향후 휴대폰 트랜드가 폴더형이라는 점에 착안하여 98년 말 애니콜 폴더를 출시하기에 이른다. 안성기의 가방을 접는 광고가 매우 인상적이었 던 애니콜 폴더는 휴대폰 시장에 폴더바람을 몰고 왔으며, 이후 경쟁사들이 서둘러 폴더제 품을 출시했으나 애니콜이 이미 기선을 잡은 후였다. 연이어 삼성전자는 또다른 힛트 제품 으로 미니 폴더를 출시한다. 크기와 미적감각에서 한층 개선된 미니폴더는 장혁이 옷을 멋 있게 입으면서 애니콜 미니 폴더로 패션을 완성하는 광고로 힛트를 쳤으며, 휴대폰을 생활 의 필수도구일뿐 아니라 패션을 리드하는 액세사리로 부각시킨 공로품이다. 이 제품의 출시 와 마케팅을 통해서 휴대폰과 패션의 만남이 본격적으로 시작되었다고 할 수 있다. 향후 이 제품은 국내외의 각종 디자인상을 수상하게 되며 이후 유럽등 패션의 본고장에서도 힛트를 치는 인기모델이 되었다. 여기에서 그치지 않고 삼성전자는 또 한번의 디자인을 통한 제품 차별화를 이끌어내는데, 바로 애니콜 듀얼 폴더이다. 듀얼 폴더는 소비자의 폴더 제품 사용 상의 불편함으로 지적되고 있던 폴더를 열어야만 화면을 볼 수 있는 문제점을 폴더 외부에 $\mathrm{LCD}$ 를 하나 더 추가한 듀얼폴더를 출시하여 해소시켰고 소비자의 만족도를 극대화하였다. 특히 차별화된 고품격 디자인을 위해 외관에는 흰색을, 키패드에는 메탈릭 컬러를 사용하고 또한 매끄럽고 부드러운 터치감을 느낄 수 있게 만들었으며 인체 공학적인 디자인을 도입하 여 사용시의 편리함과 휴대시의 안정감을 도모하였다. 듀얼폴더는 소형화와 경량화로 소용 량기준 $77 \mathrm{~g}$ 의 가벼운 무게와 고품격의 디자인으로 대부분의 사용자들이 목에 걸고 다니는 새로운 휴대폰 패션을 창출하기도 했다.

애니콜 듀얼 폴더는 다양하고 혁신적인 판매촉진으로 출시초기 붐을 조성한 것으로도 유 명하다. 출시전 예약 판매를 통한 붐을 조성하고 강남역, 압구정동등 신세대 거리를 중심으 로 한 퍼포먼스 (자전거 및 $\mathrm{TFT}-\mathrm{LCD}$ 등을 활용)활동은 새로운 프로모션 수단으로 자리를 잡 았으며, 유통점에 대한 판매지원책으로 애니콜 듀얼 폴더 판매 특공대를 조직하여 전국 주 요상권에 대리점과 공동으로 실판매를 올려주는 행사도 진행하였다. 또한 유통력 강화를 위 해 애니콜 전용 Anycall Plaza를 오픈하고 프로농구 스폰서도 맡았다. 이러한 다각적인 판 매촉진과 발신자 서비스 시작시기가 맞물려 애니콜 듀얼 폴더에 대한 폭발적인 수요가 지속 되었으며 물량부족 현상으로 한동안 곤란을 격을 정도였다.

이 시기는 신카테고리 창출을 통한 히트상품의 지속 배출로 특징지워지며, 수요는 대체수 요가 대부분을 차지했고 (대체구매 $70 \%$, 신규구매 30\%의 비율), 타겟도 Young generation으 로 완전히 하향조정되었다. 또한 애니콜 전문 포털 사이트인 "애니콜 랜드" 와의 접목이 본격적으로 이루어진 것도 이 시기 부터이다. 


\section{5 제 5 기 리뉴얼기 $(01.3$ - )}

이 시기는 CDMA2000 차세대 휴대폰 시장이 전개되고, 1925 세대가 시장의 중심으로 부상하 뎌 애니콜이 시장을 선도하는 가운데 $\mathrm{S}$ 사가 급부상하는 기간이다. 이에 삼성전자는 차세대 휴대폰에 어울리는 $\mathrm{BI}$ (Brand Identity)를 재정립하고 (표 5)(표 6) 초고속 무선 인터넷, 컬

(표 5) Brand identity (identity)

\section{Anycall Spirit: DIGIT AL BLUEISM}

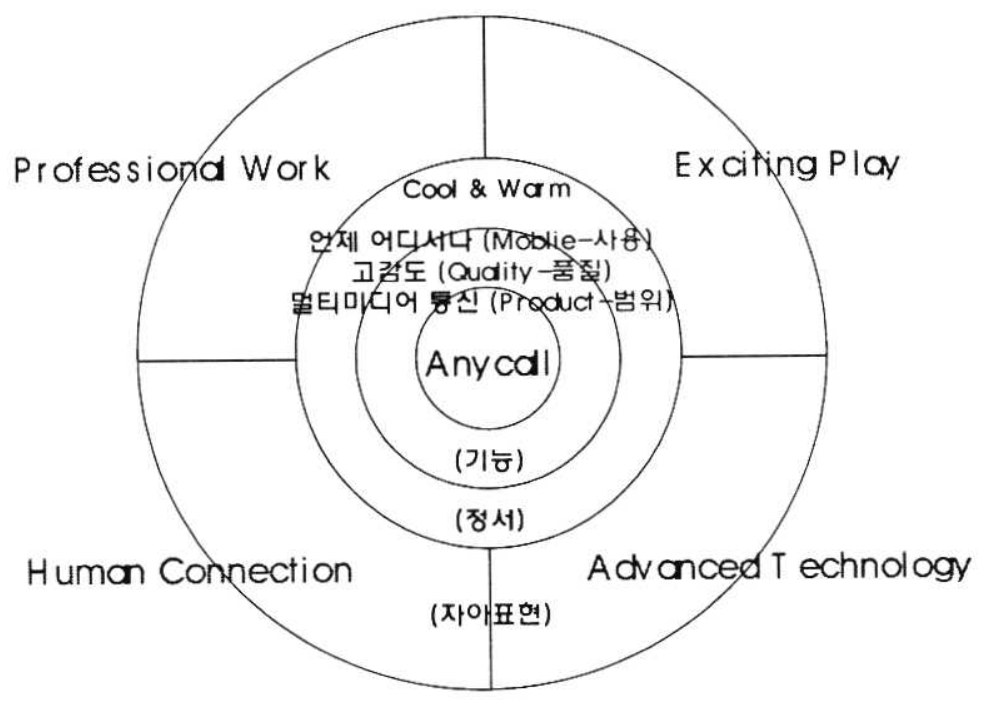

(표 6) Brand identity (로고타입 교체)

- New Visual Identity -

\begin{tabular}{|c|}
\hline 기업 자원 \\
\hline \hline 제뭄차원 \\
\hline 소비자자원 \\
\hline
\end{tabular}

Digital Image

T echnology Expression

Youthful L ook

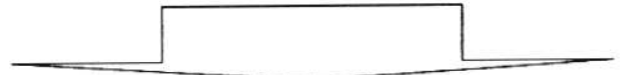

\section{Anycall $\Rightarrow$ Anycall}


러 $\mathrm{LCD}$, 카메라폰, $\mathrm{VOD}$ 폰, 64 화음 등 기능을 혁신한 제품과 진일보한 커뮤니케이션으로 대 응한다. 새로워진 애니콜의 이미지 포지셔닝은 'DIGITAL BLUEISM'이라고 명명되었는데, 첨 단기술의 도입으로 멀티미디어 통신을 더욱 더 풍부하게 하여주며, 고감도 품질을 보장하고 언제 어디서나 즐겁게 사용할 수 있는 mobile phone을 표방하고 있다. 또한 고객에게 또 하 나의 디지털 가족으로 친근하게 다가가고, 세련되게 세상을 살아가는 사람들에게 가장 잘 어울리는 필수품임을 'Cool \& warm'이라는 개념으로 설명하고 있다. 특히 선진기술로 인한 휴대폰 확대기능으로 초고속 무선 인터넷에 있어서 속도, 컬러LCD, VOD등을 경쟁 우위 포인 트로 부각시키고 있다. 타겟에 있어서는 애니콜을 진부한 브랜드로 인식하는 것을 선방어하 고 일보다는 즐거움을 추구하는 N generation에 침투하고자 노력하였다. 커뮤니케이션전략 은 ' 디지털 익사이팅 '캠페인으로 이어졌고, 안성기, 이나영, 차태현이 출연한 '컬러로 쏜다' 광고가 만들어졌다. 이 광고는 속도, 컬러, 멜로디를 테마로 한 '디지털 익사이 팅' 캠페인의 일환이다. 최근에는 카메라폰, $\mathrm{VOD}$ 폰등을 중점적으로 광고하고 있으며, 가 수 세븐을 등장시켜 64화음의 새로워진 애니콜을 랩을 삽입하여 소개하고 있다. 특히 카메 라폰은 전체 핸드폰시장의 $35 \%$ 정도나 차지하는 효자 품목이다. 카메라폰 시장에서 애니콜의 시장 점유율은 $55 \%$ 에 이른다. 한편 $\mathrm{VOD}$ 폰은 삼성전자가 최초로 개발한 모델이다. 신세대들 의 라이프스타일에 부응한 제품으로 핸드폰으로 music video도 보고, 영화도 감상하며, 실 시간대 TV수신도 가능하고, 자기의 노래솜씨로 벨소리를 장식하는 Live bell 기능까지 신세 대들을 위한 다양한 콘텐츠를 작동시키는 제품이다.

덧붙여 영타겟, 여성 등 세분화된 IMC활동을 전개하고 애니콜 랜드 리뉴얼을 통한 온라인 영역을 확대하고 있다. 특히 영 타겟중에서도 10-20대의 ting group의 부상에 따라 그들의 취향에 맞는 판매촉진 전략 (학교내에 그들이 뽑은 연예인을 출동시켜 이벤트를 여는 “SCHOOL ATTACK'과 같은 SUPRISING EVENT, 영화 MATRIX II의 시사회에서 이벤트를 여는등 ENTERTAINMENT MARKETING)도 전개하고 있다.

그 밖에도 스피커폰, MP3폰, 워치폰, 화상폰등 소비자의 새로운 욕구를 충족시키는 다양 한 제품을 한 발 앞서 개발하고 있다. 이 시기에 컬러폰 $\mathrm{M} / \mathrm{S}$ 의 $70 \%$ 를 달성하여 시장을 선 점하고 있으며, 2 위 업체와 2 배 이상 격차로 전체 휴대폰시장의 M/S $50 \%$ 대 재탈환에 성공하 였다. 국내 뿐만이 아니라 해외에서도 애니콜은 명실공히 최고의 브랜드로 선보이고 있다. 브랜드 이미지 강화를 위해 패션쇼, 영화속의 PPL(Product Placement)등을 통해 세계의 소 비자들에게 침투하고 있으며, 매트릭스 리로디드를 통한 시네마 마케팅 발표회를 85개의 개 봉국에서 열었으며, 런던 템즈강, 뉴욕 맨하탄, 파리등 세계 명소에서 잇따라 이벤트를 개 최하는둥 적극적 마케팅 공세를 펼치고 있다. 
(아래에는 앞에서 설명한 제1기에서 5 기에 이르는 동안의 브랜드전략 (표7), 시장점유율의 변화 (표8)와 브랜드 지표의 변화 (표9)를 표로 실었다.)

(표 7) Anycall brand review brief

\begin{tabular}{|c|c|c|c|c|c|}
\hline 기간 & 1 期 94.8-98.6 & 2 期 97.10-98.6 & 3 期 $98.7-99.8$ & 4 期 99.9-01.2 & 5 期 01.3 \\
\hline $\begin{array}{l}\text { MARKETING } \\
\text { SHIFT }\end{array}$ & $\begin{array}{r}\text { 차별화기 } \\
\text { FFERENTIAI }\end{array}$ & $\begin{array}{l}\text { 확장? } \\
\text { EXTENT }\end{array}$ & $\begin{array}{l}\text { 대표성호 } \\
\text { LEADER }\end{array}$ & $\begin{array}{l}\text { 세분화기 } \\
\text { ELABORAT! }\end{array}$ & $\begin{array}{l}\text { 리뉴얼기 } \\
\text { RENEWAL }\end{array}$ \\
\hline $\begin{array}{c}\text { 마케팅이슈 } \\
\text { (커뮤니케이션포인트) }\end{array}$ & $\begin{array}{l}\text { 기본성능 입중 } \\
\text { (항화풍질) }\end{array}$ & $\begin{array}{l}\text { 기본수요 확산 } \\
\text { (PCS 도입) }\end{array}$ & $\begin{array}{l}\text { 수요의 대중와 } \\
\text { (NO.1이미지) }\end{array}$ & $\begin{array}{c}\text { 대제수요 진작 } \\
\text { (쭐더/미니/듀얼) }\end{array}$ & $\begin{array}{c}\text { B। 재정립 } \\
\text { (CDMA2000) }\end{array}$ \\
\hline 슐로건 & $\begin{array}{l}\text { 한쿡지형에 } \\
\text { 강아다 }\end{array}$ & $\begin{array}{l}\text { 작은소리에 } \\
\text { 강하다 }\end{array}$ & $\begin{array}{l}\text { 언제 어디서나 } \\
\text { 안국인은 애니콜 }\end{array}$ & $\begin{array}{l}\text { 내 손안의 } \\
\text { 디지털 세앙 }\end{array}$ & 디지덜 익사이탕 \\
\hline 브랜드체계 & 삼성휴대폰 애니콜 & $\begin{array}{c}\text { 삼성 애니콜 } \\
\text { 삼성 애니꼴 PCS }\end{array}$ & 에니큘 & 애니풀 졸더 & 애니꿀 컬러 \\
\hline 강ㄱ & $\begin{array}{l}\text { 어영호/합국의자존심 } \\
\text { 안성기/폭파 外 }\end{array}$ & $\begin{array}{l}\text { 김의선,장동 건/ } \\
\text { 늘개 外 }\end{array}$ & $\begin{array}{l}\text { 박세리/ } \\
\text { 내게임욜주는소리 外 }\end{array}$ & $\begin{array}{l}\text { 안성기, 장역, 이나영/ } \\
\text { 접는가아앙 }\end{array}$ & $\begin{array}{l}\text { 안엉기, 이나영, 자태연 } \\
\text { 컬러로쏜다 外 }\end{array}$ \\
\hline IMC & 유영산 무료륭화 & $\begin{array}{l}\text { 옳림픽 스폰서쉅 } \\
\text { 사업자 훙마케힝 } \\
\text { ARS 라디오CM }\end{array}$ & $\begin{array}{l}\text { 애니콜 } \hat{\sigma} \\
\text { 애니쿨 에티켓 캠메인 }\end{array}$ & $\begin{array}{l}\text { 프로훅구 스폰서섭 } \\
\text { 온라인 (에니꼴랜드) }\end{array}$ & $\begin{array}{l}\text { ㅎ⽊ㅇ브랜드비젼 정립 } \\
\text { 로고,때키지,SIP 전환 }\end{array}$ \\
\hline $\begin{array}{l}\text { SU CCE SS } \\
\text { FACT OR }\end{array}$ & 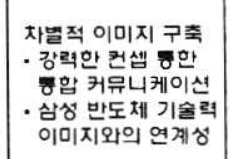 & $\begin{array}{l}\text { 브랜드 EXT ENTION } \\
\text { - 기본 이미지 강화 } \\
\text {-PCS 퉁한 시징' 확대 }\end{array}$ & $\begin{array}{l}\text { 대표이미지 크고와 } \\
\text { - 수요 대중 와ㄹㅡㅡㄹ 위한 } \\
\text { 고객참여 프로그램 } \\
\text { 확산 } \\
\text { - 문화선도 캠페인 }\end{array}$ & $\begin{array}{l}\text { 브랜드리더쉄 강와 } \\
\text { - 홯카테고리 창출 } \\
\text { - 다영애 지는 } \\
\text { 소비자 NEEDS 대요 }\end{array}$ & 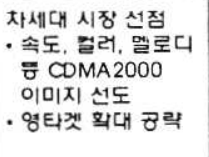 \\
\hline 미픕사8 & $\begin{array}{l}\text { 한국지영에 강아다 } \\
\text { 캠페인 장'기 운영 }\end{array}$ & 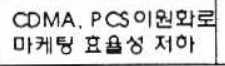 & $\begin{array}{l}\text { 제품 연계성 및 } \\
\text { 구매촉발요소미약 }\end{array}$ & $\begin{array}{l}\text { Young Generdion } \\
\text { 륙 미폽 }\end{array}$ & $\begin{array}{l}\text { 대중적 이미지로 } \\
\text { 의소성, 고큽감 익화 }\end{array}$ \\
\hline
\end{tabular}

(표8) 시장점유율의 변화

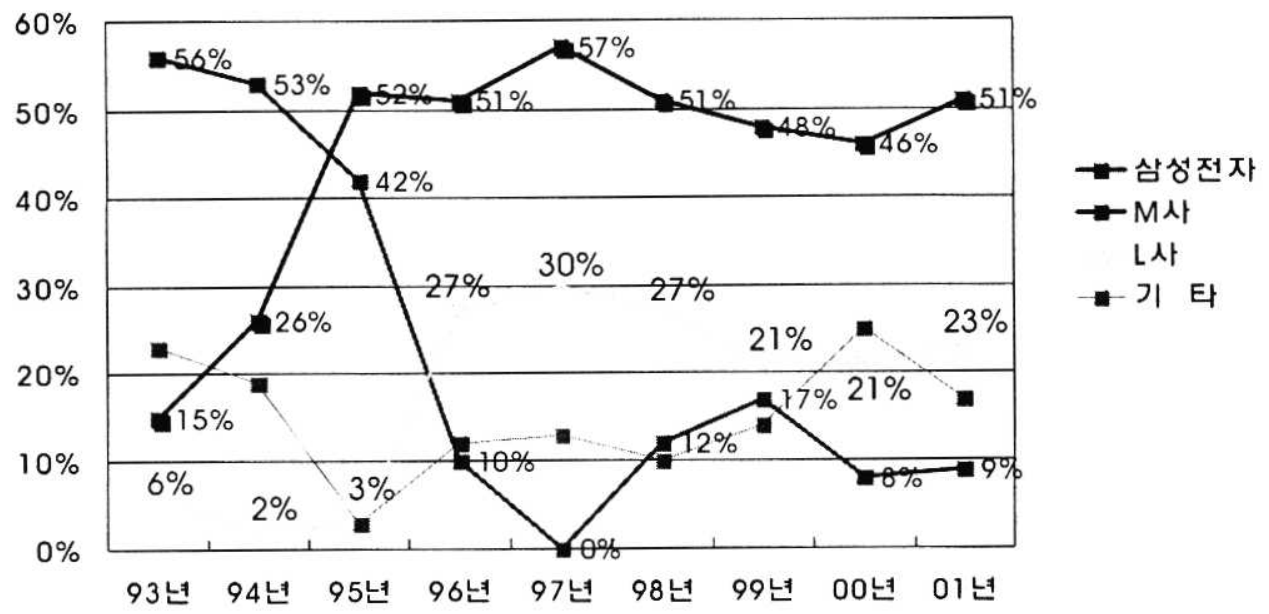


(표9) History of Anycall Brand index

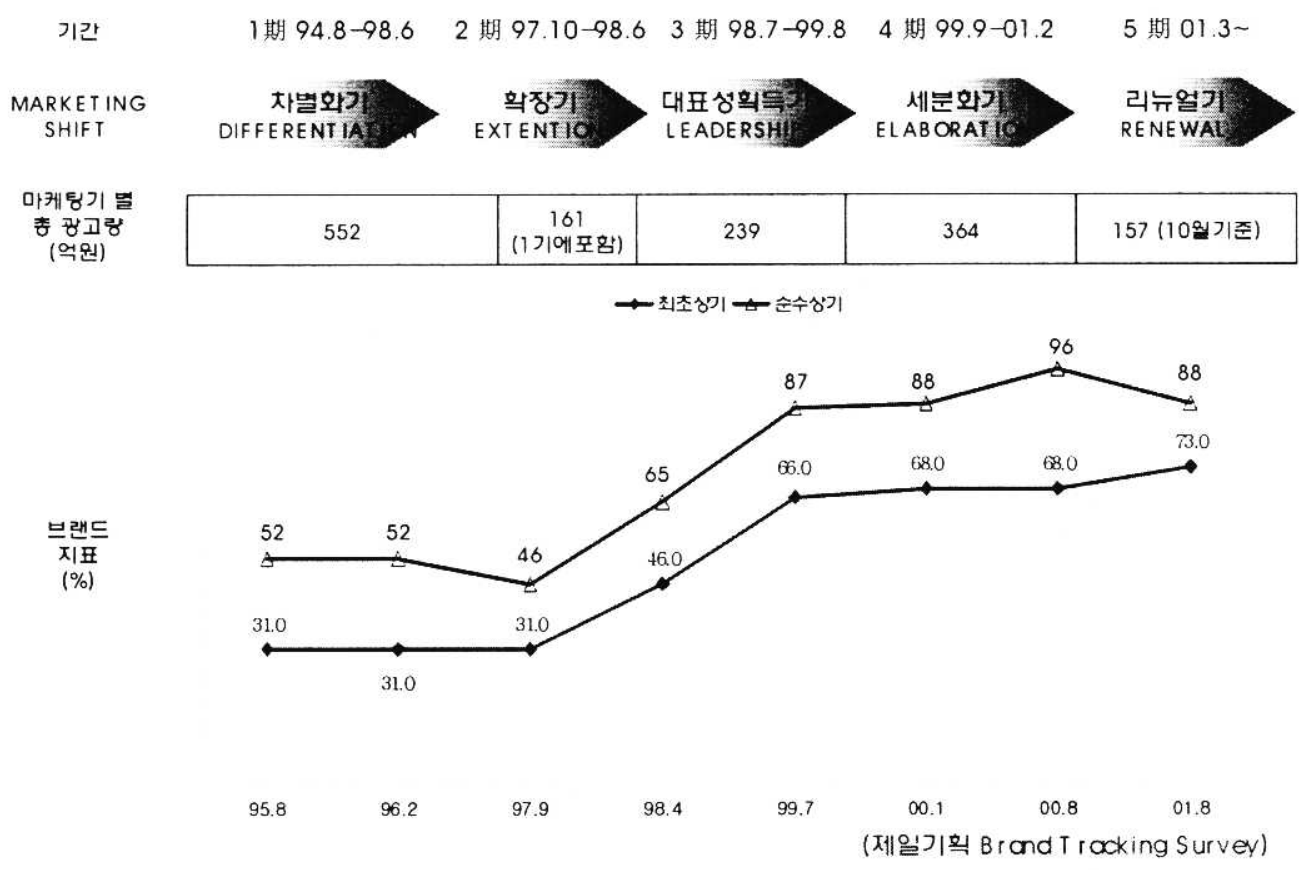

\section{4. 애니콜신화를 이끌어낸 성공요인 분석}

\section{1 한국의 자부심을 상징하는 브랜드 파워 구축}

애니콜의 신화를 창출시킨 원동력은 역시 애니콜이라는 브랜드의 구축이다. 언제 (anytime), 어디서나(anywhere) 전화를 받을 수 있는 휴대폰이라는 의미를 가진 아주 기억 하기 쉬운 브랜드명으로 시작된 애니콜은 한국인의 자부심을 상징하는 글로벌 브랜드로 성 장하였다. 이러한 브랜드파워를 구축하기까지에는 삼성전자의 시의 적절한 브랜드 전략과 그것을 효율적으로 소비자에게 인식시킨 커뮤니케이션 전략이 크게 기여한 셈이다.

애니콜의 브랜드 전략은 비교적 일관성과 보완성을 갖고 훌륭히 수행되었다. '한국지형 에 강하다' 라는 카피는 애니콜을 No.1 브랜드로 성장시킨 일등공신이었다. 국내지형에 맞 게 특수 설계된 확실한 제품력과 그것을 홍보하기 위한 천왕봉 프로젝트 등 프로모션 프로 그램의 뒷받침 없이는 그렇게 뜨거운 소비자의 반응을 얻어낼 수 없었을 것이다. 이 캠페인 이후 애니콜은 명실공히 한국 최고의 브랜드로 소비자의 마음속에 자리잡게 된다.

그 이후에도 애니콜은 끊임없는 브랜드 혁신을 계속하는데, 통화성공률에 이은 통화음질 에서의 우수성을 강조한 '작은 소리에 강하다' 라는 슬로건은 애니콜 PCS의 기술력을 소비 자에게 효과적으로 전달하는데 성공했고, 통화성공율을 강조하였던 기존의 애니콜 디지털에 
대해서도 통화음질이 뛰어나다는 인식을 가지게 함으로써 브랜드 확장에 의한 이중의 효과 를 얻어내었다.

최고의 제품력을 구현한 애니콜은 세계적 골퍼 박세리를 애니콜의 사용자로 등장시킨 광 고를 통해 세계적인 애니콜로 그 이미지를 부상시켰으며 이제는 한국의 대표 브랜드로 굳건 히 자리잡았다. 브랜드 활성화 전략의 일환으로 애니콜 송을 만들고 애니콜 에티켓 캠페인 을 벌이는등 고객참여 프로그램, 문화선도 캠페인을 전개했다. 이 전략은 그동안 통화품질 에 대한 소비자의 믿음을 바탕으로 축적된 브랜드 파워에 상품의 비속성 이미지를 추가하여 브랜드 가치를 확장시켰다. 연령과 성별, 계층, 지역을 초월한 한국인의 필수품이라는 이미 지는 '언제 어디서나 한국인은 애니콜' 이라는 슬로건과 이 슬로건을 바탕으로 한 다양한 고객접점 활동의 산물이다.

최근에 와서는 휴대폰 사용자가 2,000 만명을 넘어서는 등 통신환경이 급변함에 따라 제품 의 기본 성능을 바탕으로 소비자의 다양한 욕구가 반영된 진일보한 애니콜로 거듭나고 있다. 새로운 디자인의 트랜드를 간파한 삼성의 발빠른 폴더형 제품 출시로 폴더시장을 석권하고, 휴대폰을 생활의 필수도구에서 패션을 리드하는 액세사리로 포지셔닝시킨 미니폴더, 폴더 외부에 $\mathrm{LCD}$ 를 하나 더 달아 고객의 불편을 해소시켜 준 듀얼 폴더등으로 소비자의 욕구에 부응하는 브랜드로서 휴대폰의 트렌드를 창조해 나아갔다. 더불어 소비자의 다양한 욕구를 충족시켜 주기 위해 컬러폰, 카메라폰, VOD폰, 스피커폰, MP3폰, 화상폰등을 잇따라 성공적 으로 출시하고 있다. 이러한 제품들은 애니콜이 소비자의 욕구를 리드해가는 브랜드임을 확 인시켜주고 있으며, '내 손안의 더 큰 세상', '디지털 익사이팅' 이라는 슬로건아래 소 비자의 세련된 라이프스타일을 완성시켜주는 도구로 애니콜을 자리매김하게 하고 있다. 국 내에서의 확고한 브랜드 이미지 구축은 세계로도 진출하는 교두보를 마련해주었는데, 중국 에서는 'SAMSUNG ANYCALL' 로, 동남아나 미국, 유럽등지에서는 'SAMSUNG MOBILE PHONE'으 로 급성장을 하고있다. 이러한 삼성전자의 브랜드 파워 구축 노력은 애니콜 브랜드를 2002 년 기준으로 브랜드 자산가치 2조 380 억원(17억불)(브랬드 에쿼티 모델 2002. 7)에 달하는 글로벌 브랜드로 성장시켰다.

\section{2 첨단기술의 발빠른 도입}

애니콜의 성공적인 브랜드 구축을 제일선에서 뒷받침해 준 것은 첨단기술을 발빠르게 도 입하여 제품에 접목시킨 삼성전자의 안목이었다. 10 년동안 지속된 모토로라의 독주에 제동 을 건 것도 산악이 많은 한국지형에서 최적의 통화성공율을 구현할 수 있도록 설계하고, 휴 대폰의 무게와 부피를 최대한 줄이면서, $870 \mathrm{Kg}$ 하중을 견디어낼 수 있는 강한 휴대폰을 개 발한 삼성전자의 기술력이었다. 이러한 첫 번째 승부에 이어 애니콜을 최고의 품질을 자랑 하는 국민 브랜드로 키울 수 있었던 것은 $\mathrm{CDMA}$ 에로의 발빠른 진입이었다. 삼성전자는 애니 콜브랜드를 가지고 96 년 1월 홍콩에 이어 세계에서 두 번째로 $\mathrm{CDMA}$ (코드분할다중저속)방식 디지털 이동전화 서비스를 우리나라에서 상용화하게 된다. 이것은 CDMA 종주국인 미국조차 상용화를 시도하지 못한 상황에서 미국을 비롯한 외국 경쟁기업을 놀라게 하였으며, 적기대 응을 놓친 모토로라를 시장에서 패퇴시키는(모토로라의 점유율을 $10 \%$ 수준으로 급감) 계기가 되었다. 현재 애니콜은 코드다중분할방식 휴대폰 시장에서는 전세계 시장의 $30.7 \%$ 를 점하여 시장 점유율 1 위를 기록하고 있다. 이러한 $\mathrm{CDMA}$ 시장은 아직은 전체시장의 20 \%내외에 불과하 지만, 기술의 우수성 덕분에 점점 규모가 커지는 시장이라는 점에서, 삼성전자는 애니콜의 
지속적인 성장발판을 구축하였다고 볼 수 있다.

삼성전자는 96 년 $\mathrm{CDMA}$ 에의 성공에 이어 97 년에는 세계 최경량 $(159 \mathrm{~g})$, 최소형 $(160 \mathrm{cc})$ 모델 의 개발을 실현하고, 휴대폰의 부가기능을 향상시켰다. 구체적으로 배터리 기능면에서 삼성 전자만의 독자적인 파워 조절 시스템을 채용하고, 리튬 이온 배터리의 사용을 통해 배터리 대기시간을 최대 90 시간으로 확장하여 세계 최장의 배터리 대기시간을 구현하였다. 또한 수 신을 알리는 기능으로 벨, 진동, 램프중 선택이 가능하도록 했으며, 7 가지의 다양한 벨소리 및 2 개의 멜로디중 이용자가 자유롭게 선택할 수 있게 하여 타인의 휴대폰 소리와 차별을 할 수 있게 하였다. 이러한 기술력으로 애니콜은 최고급 브랜드 이미지를 구축하고 시장 주 도권을 확보할 수 있었다.

애니콜은 현재 컬러폰 시장의 $70 \%$ 이상, 카메라폰시장의 $55 \%$ 이상을 점령하고 있다. 한편 $\mathrm{VOD}$ 폰은 삼성전자가 세계 최초로 만든 품목으로 독주행진을 계속하고 있다. 이 VOD폰은 젊 은 세대가 갈구하는 익사이팅한 라이프스타일 창출에 일조를 하고 있다. 또 전화로 통화하 면서 상대방얼굴을 확인할 수 있는 화상폰도 출시가 임박하여 시장의 평가를 기대하고있다. 이러한 일련의 제품들은 디지털컨버젼스(digital convergence)를 추구해왔던 삼성전자의 기 술력의 산물이다.

\section{3 다각적 촉진전략}

광고캠페인과 연계된 애니콜의 다각적 촉진활동은 소비자의 마음속에 최고의 브랜드 애니 콜을 각인시키는데 결정적인 역할을 해내었다.

애니콜의 출범시 계획된 '한국지형에 강하다' 슬로건이 소비자의 인식에 자리잡는데는 삼성전자 전임직원이 함께 한 삼성휴대폰 우수성 알리기 캠페인, 천왕봉프로젝트의 공이 컸 다. 고객의 입소문을 유도한 구전 마케팅도 큰 효과를 발휘했는데, 소비자로부터 소나타에 애니콜이 깔렸는데도 망가지지 않았다는 제보, 직원 한 사람이 불이 붙어 애니콜이 타 버렸 는데도 다 녹아버리고 숫자판만 앙상하게 남은 전화가 놀랍게도 작동되더라는 제보가 광고 에 효과적으로 활용되기도 했다. 또한 애니콜로 구조요청을 하여 목숨을 건진 사례, 성수대 교 붕괴시 사건을 맨 먼저 알렸던 애니콜, 차와 함께 떨어졌으나 애니콜로 연락하여 긴급 구조 요청했던 사건등이 구전 마케팅의 소재였다.

애니콜은 98 년 국내처음으로 무선 통화기 부문의 올림픽 공식 스폰서로 참여하게 된다. 올림픽 공식 스폰서로서 올림픽 전용모델을 개발하였고, 고객참여와 주요 거래선에 대한 호 스피텔리티 프로그램도 성황리에 진행되었다. 이러한 스폰서쉅을 계기로 애니콜은 세계적인 글로벌 브랜드로 부상하게 된다.

그 외에도 다각적인 촉진 활동은 애니콜의 부동의 1 위 시장점유율을 가능하게 해주었는 데, 애니콜 듀얼 폴더 출시 초기의 다양하고 혁신적인 촉진전략은 새로운 프로모션 수단으 로 유명해 질 정도였다. 출시전 예약 판매를 통한 붐을 조성하고, 강남역, 압구정동 등 신 세대 거리를 중심으로 퍼포먼스(자전거 및 TFT-LCD등을 활용)를 행하였다. 연이어 듀얼 폴 더 초기 인지도 및 실퐌매 강화를 위한 집중적인 이벤트로 애니콜은 $\mathrm{M} / \mathrm{S} 50 \%$ 를 확보하는데 성공했다. 실판매 $\mathrm{BOOM} \mathrm{UP}$ 을 위해 밀집지역, 점두지역을 중심으로 영업지원 “특공대" 를 내보냈고, 유통점에 대한 미스테리 쇼퍼도 판매점의 듀얼 폴더 권유율을 획기적으로 올려 주었다. 타겟별 수요창출을 위해 극장가, 에버랜드, 고급 미용실 등을 대상으로 "MOVIE TOUR" “디지털 어드벤쳐" "Beauty 듀얼" 이라는 이벤트로 집중공략하기도 했다. 
그 밖에도 다양한 IMC 활동이 애니콜 브랜드의 가치를 확장시켜주는데 적극적으로 활용되 었는데. 타겟 접점 확대를 위한 활동으로 프로농구 스폰서쉽 활용, PPL(방송, 영화, 연예 인)강화, 타겟 밀집지역 대상 프로모션, On-line 활용 Two-way 이벤트, virus marketing등 도 전개하였다.

요즈음 들어서는 글로벌브랜드임을 자부하며 전세계를 향한 촉진 전략에도 힘을 쏟고 있 는데 매트릭스 II와 연계한 시네마 마케팅 발표회는 전세계 개봉국에서 이루어졌다. $21 \mathrm{C}$ 추 세에 발맞추어, 영화, 패션쇼, 세계 명소에서의 각종 이벤트등 엔터테인먼트 마케팅을 시범 적으로 펼쳐보이고 있다.

\section{4 브랜드 이미지를 강화시켜준 고가전략}

애니콜의 브랜드 이미지를 강화시켜준 것은 고가전략이었다. 삼성전자가 휴대폰 시장에 처음 진입하던 시기의 $\mathrm{SH}-700$ 제품의 경우에는 제품의 생산과 품질이 안정되면서 휴대폰 보 급화를 위해 $20 \%$ 이상의 파격적 제품가격 인하를 단행했고 청약금에 대한 소비자의 부담을 경감시켜주기 위해 최초로 청약금을 포함한 할부판매를 실시했다. 그 결과 95년 하반기에 시장점유율이 상승하기 시작하였고, 이어서 삼성전자는 사업자 공급용 $\mathrm{SCH}-100$ 을 출시하면 서부터 고가전략을 구사하기 시작한다.

모토로라에 대해 경쟁적 열위에 있었을때도 가격은 모토로라와 비슷한 위치에 포지셔닝함 으로써 소비자들로 하여금 모토로라와 동급의 제품이라는 인식을 심어주었다. 그 후에 시장 점유율 1 위에 오르고부터는 최고의 품질 이미지를 구축하기 위해서는 고가전략이 효과적이 라는 판단아래 경쟁사 대비 15-20만원 이상의 고가전략을 택하였다. 결과적으로 이 전략은 애니콜이라는 브랜드가 소비자에게 최고의 품질, 업계를 선도하는 브랬드라고 인식되는 계 기를 마련하게 된다.

이러한 고가전략은 애니콜을 글로벌 브랜드로 성장시키는데도 일조를 하였다. 애니콜이 유럽과 아시아등 국제시장에서 성공하게 된 요인을 '제일 작고, 제일 가볍고, 제일 많은 기능을 갖춘 제품을 비싸게 팔았기 때문' 이라고 보는 견해도 있다. 2001 년 10 월 출시된 $\mathrm{SCH}-100$ 의 가격은 대당 4 백 -5 백 달러 선으로 4 백 달러선을 조금 넘는 세계적인 브랜드들 (핀란드의 노키아, 미국의 모토로라, 스웨덴의 에릭슨)보다도 비싸게 책정됐다. 가격이 비 싼 반면 이어폰을 사용한 핸즈프리기능, 음성 다이얼등의 새로운 기능들이 장착됐고 무게도 제일 가벼웠다. 비싼 가격에도 불구하고 이 제품은 재고가 없어서 못 팔 지경이었고, 중국 에서는 $30 \%$ 이상 비싸게 팔아도 무서운 속도로 팔려나갔다고 한다.

이러한 가격전략은 애니콜의 선전만을 가져온 것이 아니라 세계시장에서 한국가전제품의 중저가 이미지를 개선할 수 있는 기회로 기대된다. 평균치 정도의 품질올 싼맛에 산다는 점 에 팔리던 한국의 가전 제품이 애니콜을 통하여 최고의 품질을 자랑하는 가장 비싼제품으로 세계 소비자에게 인정받게 되었다는 점은 시사하는 바가 크다.

\section{5 시장침투를 극대화한 유통전략}

애니콜 브랜드구축을 위한 마케팅 전략들이 다각도에서 일관성과 보완성을 가지고 이루어 졌다고 분석한 바 있듯이, 유통전략도 애니콜 신화창조의 일등공신이다. 삼성전자는 휴대폰 사업 이전부터 PC, 전화기, 팩스, 기타 가전제품을 판매하면서 이미 형성된 유통망이 있었 
기 때문에 유통측면에서 강점을 가지고 있었다. 이러한 강점을 바탕으로 애니콜 브랜드의 최대 노출을 꾀하고, 애니콜 클럽점을 집중 육성하여 매출기반을 조성하고, 중, 대형 대리 점을 결속시키기 위해 년 3 회 이상 신제품 발표회, 결속의 장을 마련하는 등 유통 취급도의 획기적 신장을 위한 적극적 유통전략을 전개해 나아갔다.

애니콜 전용유통체제인 애니콜 프라자도 운영하면서 애니콜 제품판매와 함께 신모델 전시, 서비스등을 강화하여 고객만족을 통해 매출증대를 달성하려고 노력하였다. 또한 애니콜 프 라자는 전국 주요대도시 핵심상권(신촌, 강남, 은행동, 남포동, 충장로 등)에 출점하여 제 품판매와 더불어 브랜드 로얄티 강화에 주력하였다. 그러한 노력의 연장선상에서 고객접점 확대의 애니콜 서비스 거점으로 삼성 서비스 센터, 애니콜 전문 서비스센터, 애니콜 프라자 등에서 다양한 서비스로 고객 편리성을 확대하여 실판매를 측면지원 하였다. 또한 한국전자 유통(리빙 프라자)내에 애니콜 판매점을 입점시켜 유통의 다각화도 꾀하였다. 이러한 다각 적인 유통망의 결속을 위해 판매점들간의 애니콜 가족화작업도 추진되었다.

전략적인 유통망의 확대와 유통점간의 결속은 애니콜 브랜드의 시장 침투를 효과적으로 극대화하는데 크게 기여하였다.

\section{6 고객을 향한 $\mathrm{CS}$ 향상 추진 전략}

애니콜 신화도 역시 고객의 욕구를 지속적으로 만족시켜줌으로써 가능했다는 점은 여느 세계적 파워 브랜드와 다를 바가 없다. 애니콜의 탄생부터가 고객을 향한, 고객을 위한 정 신과 자세의 소산물이었다. 이러한 정신과 자세는 고객을 향한 $\mathrm{CS}$ 향상 추진전략으로 구체화 된다. 상품기획, 개발, 제조, 마케팅, 판매, 물류, 서비스에 이르기까지 전사적 협업화를 이루는데 있어 그 구심점은 역시 고객만족이었다. 고객접점 대응력을 혁신하고, $\operatorname{VOC}\left(V_{0}\right.$ ice of Customer) 종합분석 및 경영정보화를 이루고, 지속적인 고객만족도 제고를 추진한 결과, 미디어 리서치 분석결과에 의하면 CSI(Customer Satisfaction Index)경쟁지수 $114 \%$ 를 달성 했다 (표 10). 이 조사에서는 특히 삼성 애니콜이 경쟁사에 비해 성능에서 우수한 평가를 받는 것으로 나타났다.

(표 10 ) CSI 조사 결과

조사기관 : (주) 미디어 리서치

- 표본크기 : 760 명

- 자료수집방법 : 구조화된 설문지를 통한 가구방문 대인 면접조사

\begin{tabular}{|c|c|c|c|c|c|}
\hline \multicolumn{2}{|c|}{ 구분 } & 중요도 & 삼성 & $\mathrm{L}$ & 경쟁지수 \\
\hline \multicolumn{1}{|c|}{ 체감만족도 } & 1.0 & 66 & 58.1 & 114 \\
\hline \multirow{4}{*}{ 차원 } & 고장/견고성 & 0.10 & 71 & 64.4 & 110 \\
\cline { 2 - 6 } & 성능 & 0.55 & 68.6 & 59.0 & 116 \\
\cline { 2 - 6 } & 사용편리성 & 0.08 & 68.6 & 65.8 & 104 \\
\cline { 2 - 6 } & 디자인 & 0.13 & 69.2 & 64.7 & 107 \\
\cline { 2 - 6 } & 영업서비스 & 0.05 & 67.8 & 65.1 & 103 \\
\cline { 2 - 6 } & $\mathrm{A} / \mathrm{S}$ & 0.10 & 65.6 & 59.4 & 110 \\
\hline
\end{tabular}


전사적인 $\mathrm{CS}$ 향상 추진방향으로는 경쟁열위제품 ZERO화에서 더 나아가 차별적 경쟁우위를 확보하여 경쟁지수 110 \%이상 을 확보하고, 전략제품, 전략과제를 선정하여 전략적 선택과 집중의 묘를 살리고, CSI경쟁지수중에서도 로열고객율을 중시하고, 제조, 영업, $\mathrm{A} / \mathrm{S}$ 에서 부 문별로 책임개선을 실시하도록 하였다.

이러한 고객만족을 위한 노력이야말로 애니콜브랜드가 출범한지 10 년도 안되어 브랜드 자 산가치 2조 380 억불 (17역불)에 이르는 메가 브랜드로 키워낸 원동력이었다고 할 수 있다.

\section{5. 향후 브랜드 성공을 위한 제언}

첫째, 지속적인 브랜드 이미지 제고노력이 있어야 한다.

애니콜의 지속적인 브랜드 이미지 제고를 위해서는 제품의 시장선점과 타겟에 정확하게 소 구하는 커뮤니케이션 전략이 무엇보다도 필요할 것 같다. 애니콜은 지속적으로 제품력에서 flagship을 추구해왔다. 폴더시장개척, 컬러폰시장/ 카메라폰 시장 선점, 독자적인 VOD폰 출시. 연이은 화상폰의 개발... 소비자들은 시장 개척자의 명성을 존중한다. 삼성전자의 디 지털 컨버젼스 추구전략과 소비자 라이프스타일에 대한 선견력은 애니콜브랜드의 새로운 디 지털 제품들을 어떤 경쟁사보다도 신속하게 출시하리라 기대한다. 그러한 제품들이 소비자 의 라이프스타일을 창출하고 유도해 갈 때 애니콜은 소비자들로부터 더 큰 브랜드 충성도를 기대할 수 있을 것이다.

제품력에 있어서의 선점효과를 노리는 전략이 활성화되기 위해서는 타겟에 대한 명확한 이해와 적절한 접근이 필수적이다. 특히 휴대폰소비를 선도하는 신세대에 대한 이해와 그들 에 대한 봉사정신이 접목되어야 할 것이다. 애니콜은 신세대에게 즐거움과 꿈과 열정을 선 사한다는 개념으로 접근하고 있다. 즐거움과 꿈과 열정이 요즈음 신세대의 키워드라면, 그 들이 즐겨쓰는 형용사를 통해 그들의 라이프스타일에 접근할 수도 있다. 예를들어 ting group은 빠른 속도로 부상하고 있으며, 향후 몇 년 이내에 그들이 휴대폰의 주축세력으로 성장할 것이다. 그들에게 적합한 테마를 추출해내고 그 테마를 휴대폰 기술로 접목시키는 작업, 그리고 커뮤니케이션을 통해 확산시키는 작업등이 지속적으로 전개되어야 할 것이다. 그러한 측면에서 애니콜의 리뉴얼은 푈수적이었고 한번의 작업으로 끝나는 것이 아니라 지 속적인 노력이 이루어져야 한다. 디지털 익사이팅에 이은 또 하나의 슬로건이 young generation의 꿈과 열정을 발아시킬 수 있다면 애니콜은 그들에게 최고의 친구로 대접받을 것이다. 그러한 일련의 전략적 전개는 향후 애니콜의 브랜드 자산을 지금의 몇배로 키울지 도 모른다.

둘째, 경쟁사에 대한 적시 대응이 중요하다.

앞으로 경쟁이 더욱 심화되고 가속화되리라는 것은 자명한 일이다. 지금 시장에서 파이를 키우고 있는 LG, Sky, KTFT, Motorola, Pantech-Curitel의 공격에 적시대응하지 못하면 시 장점유율은 언제라도 줄어들 수 있다. 적시대응을 위해서는 경쟁사의 동향을 항상 예의 주 시하여야 한다. 어떠한 공격에도 유연한 자세로 최고급의 차별화된 이미지를 유지하는 것이 시장선도자로서의 전략이 될 것이다. 
셋째, 고객의 신뢰를 강화하는 서비스 SYSTEM화가 구축되어야 한다.

휴대폰의 수요는 대체수요가 $70 \%$ 를 차지한다. 신세대들에게 휴대폰 교체주기는 일년이 채 안되는 몇 개월에 불과하다. 이러한 사실은 휴대폰에 있어서 after service의 중요성, 브랜 드 충성도의 중요성을 새삼 느끼게 한다. 따라서 고객과의 밀접한 관계를 형성하고 만족과 신뢰를 심어주기 위한 서비스의 SYSTEM화는 앞으로의 마케팅 전개에 필수적이다. 고객 서비 스의 뒷받침을 받을 때 제품력의 선도나 브랜드 이미지 강화 전략은 시너지 효과를 얻게 될 것이다.

넷째, 판매 $\mathrm{BOOM} \mathrm{UP}$ 을 위한 촉진 전략의 적극적 전개가 이루어져야 한다.

애니콜은 entertainment marketing 이라는 테마아래 다양하고 적극적인 촉진전략을 전개해 나가고 있다. 영화속의 PPL 및 시사회와 연계한 마케팅 발표회, 유명도시에서의 이벤트, ting group 공략을 위한 'school attack', 패션쇼 후원, 특히 올림픽 공식 후원사로서의 활동 등의 다양한 촉진 전략의 적극적 전개를 통해서 애니콜은 국내는 물론 세계 소비자에 게 사랑받는 생활의 파트너로 거듭날 수 있을 것이다. 이러한 촉진활동의 적극적 전개로 시 장점유율을 늘려갈 수 있을 것이다.

우리나라를 대표하는 글로벌 브랜드임을 자부하는 애니콜은 '우리도 하면 된다' 는 삼성 전자 애니콜 사업부의 신념이 일궈낸 하나의 신화이다. 애니콜은 그동안의 우리나라 제품의 중저가 이미지를 씻고 세계인의 손에서 제일 비싼 제품, 최고급의 제품으로 사랑받고 있다. 애니콜은 우리나라 경제의 도약을 상징한다. 지금까지의 애니콜 도약과정은 우리 제품의 일 류화 가능성을 검증해 주었다. 애니콜은 앞으로도 지속적인 제품개발과 마케팅 노력으로 우 리 제품의 고급 이미지 구축에 견인차 역할을 해주기를 기대한다. 


\section{<참고문헌>}

애니콜 신화와 그 이후 (2000, 7) 삼성전자 주식회사

삼성 Anycall 폴더 마케팅 case study (2001. 1) 삼성전자 주식회사

애니콜 마케팅 성공사례 (2001. 10) 삼성전자 주식회사

삼성VS 모토로라 소비자 만족도 조사 (1995. 8) 제일기획

삼성 Anycall Brand 호감도 조사 (2001, 6) 중앙리서치

삼성 Anycall Brand value 조사 (2001. 7) 제일기획

삼성 Anycall Brand Tracking Survey (2001. 8) 제일기획

삼성 Anycall CSI 조사 (2001. 10) 미디어 리서치

브랜드 에쿼티 모델 (2002. 7) 한국생산성 본부 (고려대 박찬수 교수 발표), 산업자원부 